DOI: 10.35757/RPN.2010.18.09

Wanda Jarzabek

\title{
WIZYTA POSŁA STANISŁAWA STOMMY \\ W RFN W 1969 ROKU - PRZYCZYNEK DO BADAŃ NAD TRUDNOŚCIAMI W FUNKCJONOWANIU PÓŁOFICJALNYCH KANAŁÓW KONTAKTÓW W PROCESIE NORMALIZACJI STOSUNKÓW PRL-RFN
}

W sytuacji braku regularnych stosunków dyplomatycznych między PRL a RFN prowadzenie rozmów dwustronnych bywało kłopotliwe. Od lat pięćdziesiątych XX wieku, szczególnie po 1955 roku, gdy zaczęto podejmować próby nawiązania kontaktów dwustronnych, szczególną rolę odgrywały kontakty pomiędzy dziennikarzami, dyplomatami polskimi i zachodnioniemieckimi w krajach trzecich; $\mathrm{w}$ celu nawiązania stosunków dwustronnych strona niemiecka w latach sześćdziesiątych korzystała także z usług przemysłowców ${ }^{1}$. Ważną rolę $\mathrm{w}$ przezwyciężaniu animozji polsko-niemieckich odgrywały Kościoły katolicki i ewangelicki, a także niektóre osobistości. Szczegól-

1 W. Jarząbek: W poszukiwaniu porozumienia z Republika Federalna Niemiec - tajne rozmowy z Albrechtem von Kesselem w Waszyngtonie w 1957 roku, "Rocznik Polsko-Niemiecki” 1999, t. 8, Warszawa 2000; eadem: W sprawach niemieckich nasz głos musi mieć swa wagę..." Problem niemiecki w polskiej polityce zagranicznej w latach 1956-1958, „Dzieje Najnowsze” 2001, nr 2, s. 103 i n.; eadem: Problem niemiecki w polskiej polityce wobec mocarstw zachodnich i państw niezaangażowanych w czasie drugiego kryzysu berlińskiego 1958 -1962 (wybrane zagadnienia), w: Polska - Niemcy - Europa, Księga jubileuszowa z okazji siedemdziesiatej rocznicy urodzin Profesora Jerzego Holzera, Warszawa 2000, s. 215 i n. 
ną postacią zaangażowaną $\mathrm{w}$ proces pojednania polsko-niemieckiego był Stanisław Stomma ${ }^{2}$.

Gdy po wyborach do Sejmu w styczniu 1957 roku miejsce na ławach poselskich zajęli też posłowie katoliccy z grupy „Znak”, Stanisław Stomma jako jeden $\mathrm{z}$ nich został wiceprzewodniczącym sejmowej Komisji Spraw Zagranicznych. Ze względu na swoje kontakty międzynarodowe i związane z tym podróże miał on też możliwość spotykania się z politykami i dyplomatami zachodnimi, $\mathrm{w}$ tym zachodnioniemieckimi.

Pewne aspekty problemu niemieckiego, przede wszystkim brak międzynarodowego uznania granicy na Odrze i Nysie Łużyckiej, były przedmiotem troski nie tylko ówczesnych władz PRL, ale także środowisk pozarządowych oraz emigracji polskiej w krajach zachodnich, w tym środowisk związanych z władzami na Wychodźstwie.

Poseł Stanisław Stomma w czasie swoich podróży odbywanych często na zaproszenia środowisk katolickich uczestniczył w spotkaniach z osobami mającymi wpływy polityczne, a także politykami wysokiego i najwyższego szczebla.

Ówczesne władze wyrażały zgodę na takie spotkania, prosiły na ogół o pozostawanie w trakcie podróży w kontakcie z polskimi placówkami oraz informowanie o rozmowach ${ }^{3}$. Podobnie było $\mathrm{w}$ przypadku wizyty, do której doszło w październiku 1969 roku.

Wizyta nastąpiła $\mathrm{w}$ niezwykle ważnym momencie. Po chwilowym zahamowaniu kontaktów Wschód-Zachód, spowodowanym interwencją wojsk Układu Warszawskiego w Czechosłowacji, wiosną 1969 roku powrócono do rozmów. Nastąpiła jednak istotna zmiana - spadło znaczenie poszczególnych państw Europy Wschodniej jako podmiotów różnych działań, Moskwa uzyskała potwierdzenie praw w swojej strefie wpływów i stała się też głównym, a nawet, co ważniejsze, w owym czasie jedynym obiektem zabiegów dyplomatycznych ze strony Bonn. Wzbudziło to zaniepokojenie Warszawy i wpłynęło na zwiększenie ak-

2 S. Stomma: Pościg za nadzieja, Paryż 1991; W. Peiler: Na przekór fatalizmowi wrogości. Stanisław Stomma i stosunki polsko-niemieckie, Warszawa 1998.

3 Notatka S. Stommy dla ministra A. Rapackiego sporządzona po podróży opublikowana w: W. Jarząbek, Wizyta posła Stanisława Stommy w RFN w 1958 roku, „Rocznik Polsko-Niemiecki" 2009, t. 17, s. 135 i n. We wstępie do dokumentu omówione zostały też inne przykłady kontaktów politycznych S. Stommy nawiązanych w tym czasie. 
tywności zarówno w planowaniu dotyczącym konferencji europejskiej i propagowaniu własnych koncepcji jej agendy i dokumentów końcowych, jak też w polityce niemieckiej, czego kulminacją stało się przemówienie wygłoszone przez Władysława Gomułkę 17 maja 1969 roku. Propozycja podjęcia rozmów z RFN nie spotkała się z szybką odpowiedzia, co wynikało w dużym stopniu z sytuacji wewnętrznej w RFN - w okresie przedwyborczym rząd nie chciał podejmować żadnych trudnych decyzji. Po wyborach, które odbyły się 28 września 1969 roku, Warszawa także nie była pewna, jaka będzie odpowiedź na jej propozycje. Dopiero $\mathrm{w}$ deklaracji przedstawionej przez nowy rząd z Willy Brandtem na czele 28 października pojawiła się informacja, że rządowi PRL zostanie zaproponowane podjęcie rozmów, ale bez podania szczegółów ${ }^{4}$.

Po wyborach, ale jeszcze przed przedstawieniem przez rząd RFN programu rządowego, do Niemiec na zaproszenie „Bensberger Kreis” wyruszał Stanisław Stomma. Miał uczestniczyć w spotkaniu koła oraz wygłosić kilka wykładów na zaproszenie różnych stowarzyszeń. Wrażenia dotyczące nastrojów panujących w Niemczech na temat warunków normalizacji byłyby dla ówczesnego kierownictwa MSZ cenną informacją ze względu na generalnie ograniczone możliwości czerpania wiadomości u źródeł. Kolejnym etapem podróży była Francja.

Stomma wyjechał do Bonn 5 października. Trasa prowadziła przez Wiedeń. W depeszy wysłanej po pierwszych rozmowach pisał m.in. o tym, że deputowany CDU Herbert Czaja wyraził pogląd, że uznanie polskich granic powinno być uzależnione od ustępstw strony polskiej, $\mathrm{w}$ tym rezygnacji z odszkodowań ${ }^{5}$. 14 października do MSZ dotarła wiadomość od korespondenta PAP na temat relacji z rozmowy ze Stanisławem Stommą zamieszczonej we „Frankfurter Rundschau”. Poseł miał rzekomo powiedzieć (sam określił publikację jako niefortunną i starał się ją sprostować), że Polska ma nadzieje na uznanie granicy w ciągu czterech lat oraz że normalizacja stosunków nie musi być poprzedzona uznaniem NRD przez RFN. Za „sympatyczny rozwój” nastrojów, we-

4 D. Bingen: Polityka Republiki Bońskiej wobec Polski. Od Adenauera do Kohla 1949-1991, Kraków 1997, s. 115.

5 AMSZ, Dep. IV, z. 22/76, w. 5, Szyfrogram Piątkowskiego do Willmanna, 13 października 1969. 
dług gazety, miał uznać to, że RFN nie uważa już Europy Wschodniej za „polityczną pustynię"6.

Niezależnie od tego, że rzeczywiście nastąpiło pewne osłabienie nacisku władz PRL na spełnienie przez RFN pakietu warunków uzgodnionych w Warszawie w lutym 1967 roku$^{7}$, ze względów politycznych - relacji wewnątrzblokowych, szczególnie z NRD i Moskwą - publiczne wzmianki na ten temat, szczególnie ze strony posła, były wysoce niepożądane. Dyrektor Departamentu IV (Europa Zachodnia) Adam Willmann depeszował do Kolonii: „Prosimy nawiązać z nim [S. Stommą - W.J.] szybko odpowiedni kontakt, przypomnieć, że wypowiedzi polityczne i oświadczenia dla prasy wymagają uzgodnienia z Placówką i wytknąć niewłaściwość tego stanowiska opublikowanego we Frankfurter Rundschau" ${ }^{\prime 8}$.

Dzień później pracownik ambasady, Ernest Kucza, informował o rozmowie telefonicznej z posłem Stomma, który był zdziwiony publikacja gdyż jego zdaniem rozmowa miała luźny charakter. Sygnalizował też, że mógłby dokonać sprostowania w wywiadzie, którego udzielenie proponował mu Klaus von Bismarck'. Na marginesie depeszy z 16 października, Willmann proponował, aby zasugerować posłowi nieudzielanie wywiadu. Chyba to uczyniono, niemniej w szyfrogramie z 21 października Piątkowski pisał, że Stomma udzielił wywiadu wraz z innymi członkami „Bensberger Kres” i jego wypowiedź była przez szefa Misji oceniana pozytywnie. Przekazał więc sugestię, aby Warszawa nie nakazywała podjęcia akcji w celu wstrzymania nadania. Tak też się stało.

Stomma, za pośrednictwem szefa Przedstawicielstwa Handlowego Piątkowskiego, depeszami informował o kolejnych spotkaniach, również z prezydentem RFN Gustavem Heinemannem ${ }^{10}$.

6 Tłumaczenie fragmentów korespondencji w biuletynie PAP dla MSZ „W oczach Zachodu", nr 1836/14/10.1969.

7 W. Jarząbek: Doktryna Ulbrichta czy doktryna Gomułki? Polska a koordynacja polityki bloku wschodniego wobec Ostpolitik w latach 1966-1967, „Dzieje Najnowsze” 2005, nr 3, s. 26 i n.

8 AMSZ, Dep. IV, z. 22/76, w. 5, Szyfrogram Willmanna do Piątkowskiego, 15 października 1969. 1969.

AMSZ, Dep. IV, z. 22/76, w. 5, Szyfrogram Kuczy do Willmanna, 16 października

${ }^{10}$ AMSZ, Dep. IV, z. 22/76, w. 5, Szyfrogram Piątkowskiego do Willmanna z 21 października (o rozmowach z Georgiem Leberem, Ernstem Majonica, Helmutem Kohlem). 23 października przesłano depeszą relację o rozmowie z prezydentem RFN. 
Niemniej wypowiedź z początku podróży musiała wywołać irytację, a niewykluczone, że także interwencję ze strony Berlina Wschodniego. W odręcznej notce zamieszczonej na tekście depeszy informującej o rozmowie z prezydentem Heinemannem minister Stefan Jędrychowski prosił Willmanna o sprawdzenie, jak długo S. Stomma miał jeszcze podróżować po RFN, gdyż miał wytyczne, aby go „odwołać ze względu na niefortunne wypowiedzi dla Frankfurter Rundschau"11.

28 października Willmann depeszował do Piątkowskiego: „Prosimy powiadomić Stommę, że jego pobyt w NRF należy możliwie natychmiast zakończyć. Sprawa uzgodniona z władzami Sejmu. Najlepiej by było jakby wrócił wprost do Polski" ${ }^{12}$. Poseł Stomma udał się już jednak do Paryża, w którym przekazał ambasadorowi Tadeuszowi Olechowskiemu sporządzoną 27 października notatkę relacjonującą pobyt w RFN. Została ona w dwóch egzemplarzach przesłana przez kuriera do Warszawy 30 października, dotarła 3 listopada, a 5 listopada ambasador Adam Willmann przesłał notatkę do wiceministra Józefa Winiewicza $^{13}$.

Po powrocie do kraju w notatce do ministra Stefana Jędrychowskiego Stanisław Stomma ustosunkował się do publikacji we „Frankfurter Rundschau". Przekazał, że starał się ograniczać kontakty polityczne, a te, do których doszło, „dobrze służyły polityce polskiej”.

Obydwie notatki Stanisława Stommy publikujemy w niniejszym numerze "Rocznika Polsko-Niemieckiego". Jeśli chodzi o notatkę sporządzoną w Paryżu, drukowana jest wersja z notatkami odręcznymi Józefa Czyrka.

Notatki pokazują duże zaangażowanie S. Stommy w proces pojednania polsko-niemieckiego oraz trudności, które wynikały dla władz z tego powodu. MSZ wykorzystywał także tę możliwość uzyskania informacji o polityce RFN, ale równocześnie kierownictwo MSZ oraz pracownicy resortu nie byli wolni od ograniczeń politycznych i ideolo-

\footnotetext{
${ }^{11}$ AMSZ, Dep. IV, z. 22/76, w. 5, Szyfrogram Piątkowskiego do Willmanna, 23 października 1969.

${ }_{12}$ AMSZ, Dep. IV, z. 22/76, w. 5, Willmann do Piątkowskiego, 28 października 1969.

${ }_{13}$ AMSZ, Dep. IV, z. 22/76, w. 5, pismo przewodnie T. Olechowskiego wraz z notatkami odręcznymi A. Willmanna.
} 
gicznych oraz nierzadko byli przewrażliwieni na punkcie ewentualnego wchodzenia $w$ ich kompetencje. Wrażliwe było też prawdopodobnie kierownictwo państwa. Niewykluczone, że wezwanie S. Stommy do kraju zostało zlecone przez W. Gomułkę, szczególnie przeczulonego na punkcie wyłączności władz do kierowania polityką niemiecką.

Obydwie notatki są przechowywane w: AMSZ, Dep. IV, z. 22/76, w. 5. 
Dr STANISEAW STOMMA Poseł na Sejm Warszawa, ul. Kanonia 24/26

tel. 31-60-76
Warszawa, dnia 18 listopada 1969 r.

Panie Ministrze!

12.XI.b.r. wróciłem do Warszawy po dłuższym pobycie za granica. Przez przeszło dwa tygodnie bawiłem w NRF, gdzie miałem wiele rozmów o znaczeniu politycznym, a także byłem przyjęy przez Prezydenta Heinemanna (20.XI.b.r.) ${ }^{1}$. O rozmowie z Prezydentem, a także z innymi niemieckimi politykami przesłałem krótkie sprawozdanie do MSZ na ręce p. Ambasadora Willmanna. Przesłałem je z Paryża za pośrednictwem naszego Ambasadora.

Czuję się w obowiazku złożyć Panu Ministrowi moje wyjaśnienia w tej sprawie.

Do NRF udałem się na zaproszenie kierownictwa "Bensberger Kreis". Byłem z góry proszony o szereg spotkań z różnymi środowiskami społeczeństwa zachodnio-niemieckiego. Zaproszenie to, ściśle personalne, dotyczyło mnie oczywiście jako posła, przewodniczacego Koła Posłów "Znak" i przeto w założeniu miało charakter polityczny. Zdajac sobie z tego sprawę, podkreślałem zawsze bardzo skrupulatnie, że przez nikogo nie jestem delegowany, że sfer rzadzacych w Polsce nie reprezentuje i że wypowiadam poglady tylko osobiste.

Ponieważ pojawiły się bardzo niefortunne komentarze prasowe ("Frankfurter Rundschau"), przeto uznałem za słuszne udzielenie jednego wywiadu, który by sprawę wyjaśnił, przecinajac dalsze dowolne komentarze. W ramach posiedzenia "Bensberger Kreis" udzieliłem wywiadu telewizji i wywiad ten - z dodaniem dwóch pytań dotyczacych Kościoła w Polsce - pozwoliłem powtórzyć w tygodniku "Publik", który jest organem episkopatu niemieckiego.

\footnotetext{
1 Pomyłka autora. Powinno być 20 października.
} 
Za ten wywiad przyjmuje pełną odpowiedzialność. Wydaje mi się, że jest on z punktu widzenia polityki polskiej nienaganny. Nie biorę natomiast odpowiedzialności za żadne inne komentarze.

Pismo "Publik" podało mój wywiad w bardzo niestosownym zestawieniu. Zaprotestowałem ostro przeciw temu i uzyskałem zapewnienie, że redakcja da w najbliższym numerze wyjaśnienia i wyrazi ubolewanie. Przykrości z prasa sa niestety w tamtych warunkach w praktyce nie do uniknięcia ze względu na jej ogromne rozzuchwalenie i brak poczucia odpowiedzialności.

Jadac do NRF zdawałem sobie sprawę, że będę miał bardzo trudna sytuacje. Nastapiło gwałtowne zdynamizowanie polityki niemieckiej w odniesieniu do Polski, wywołane mowa Władysława Gomułki z 17 maja 1969, przeto było jasne, że przyjazd mój będzie budził duże zainteresowanie i że będę chwycony w tryby licznych kontaktów politycznych. Z drugiej strony, zupełnie nowa sytuacja stwarzała trudności w zajmowaniu stanowiska.

Dlatego starałem się zachowywać wielka ostrożność i dla uniknięcia fałszywych wersji, poglady przez siebie wypowiadane streściłem w wywiadzie dla "Publik". Uważałem również za wskazane zachowanie pewnej powściagliwości i kontakty swoje ograniczałem do tych, które wydawały mi się najważniejsze.

Twierdzę natomiast, z najgłębszym przekonaniem, że wszystkie rozmowy, które miałem z niemieckimi politykami, łacznie z audiencja u Prezydenta Heinemanna, dobrze służyły polityce polskiej.

Gdy chodzi o dalszy rozwój sytuacji politycznej w Niemczech, jestem bardzo ostrożny w optymizmie. Wydaje mi się, że weszliśmy w relatywnie niezła fazę, ale można mieć obawy, czy nie będzie to faza przejściowa. Istnieje duże prawdopodobieństwo, że na dalsza metę układ faktów stwarzać będzie sytuację dla nas trudniejsza.

$\mathrm{Na}$ nasza rzecz działa polityczny nurt pro-polski wywodzacy się z motywów moralnych. Ludzie ci chca porozumienia z Polska, uważajac je za ważne ze względów psychologicznych. Sadza, że ugoda $z$ Polska podniesie morale narodu niemieckiego i bardzo wzmocni jego prestige w świecie, a w dalszej konsekwencji zacznie dawać korzystne następstwa polityczne. Nurt ten w społeczeństwie ma raczej 
charakter elitarny, ale ze względu na wybitne jednostki, które go reprezentuja, posiada znaczna siłe. Ludzi tych należy ośmielać, ukazujac, że znajduja oddźwięk po naszej stronie.

Jesteśmy świadkami reorientacji polityki niemieckiej względem Polski i obozu socjalistycznego, ale wydaje sie, że nowe koncepcje jeszcze sie nie wykrystalizowały. Problemy uznane zostały za otwarte, sa rozważane, dyskutowane. W tym stanie rzeczy nasze kontakty z niemieckimi politykami nabieraja szczególnej wagi. Ponieważ byłem w tej sytuacji, że proponowano mi rozmowy $z$ wielu najwybitniejszymi niemieckimi politykami, moje poczucie patriotycznej odpowiedzialności nie pozwoliło mi się od nich uchylać, choć na pewno byłoby to wygodniejsze.

Proszę uprzejmie Pana Ministra o łaskawe przyjęcie mnie, abym miał możliwość przedstawić moje obserwacje i wnioski z mego pobytu w Niemczech Zachodnich.

Raczy Pan Minister przyjać zapewnienia mego głębokiego szacunku i poważania

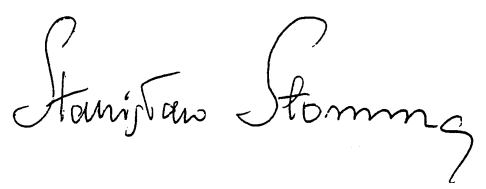

Załacznik do pisma

Nr D.IV-O-NRF $45-2-69$

Załacznik do pisma Nr 0-24-61-69

Panie Ambasadorze,

Ponieważ wrócę do Warszawy dopiero około 10 listopada, uważam za właściwe przesłać Panu już teraz krótkie sprawozdanie z mego pobytu w Niemieckiej Republice Federalnej. Szczegółowymi wyjaśnieniami służę zaraz po powrocie.

Jak przewidywałem, od pierwszej chwili tworzyła się możliwość bardzo licznych kontaktów z osobami o dużej randze politycznej. Kontaktów tych nie potrzebowałem szukać były mi one proponowane przez przyjazne osoby, inte- 
resujace się moim pobytem w tym kraju. Zwłaszcza Dyrektor Radia Zach.-Niemieckiego Claus Bismarck oraz Red. "Die Zeit" pani Dönhoff ${ }^{2}$. Mogę stwierdzić, że w praktyce miałbym możność spotkania każdej osobistości politycznej, która by mnie interesowała. Z możliwości tej korzystałem raczej powściagliwie, nie chcac by powstało wrażenie, że przyjechałem z jakaś misja i goraczkowo szukam spotkania z politykami. Dlatego np. mimo wielu propozycji, nie skorzystałem $z$ karty wstępu do Bundestagu na dwa pierwsze posiedzenia. Wydawało mi się bowiem, że moje przebywanie za kulisami parlamentu w dniu posiedzenia mogłoby być rozumiane jako łowienie polityków.

W rezultacie ograniczyłem się do spotkań mało licznych z osobami, które wydawały mi się rzeczywiście interesujace i znaczace. Spośród wpływowych polityków C.D.U., byli to deputowani: H. Köppler, Marx, Majonica, Dr Kohl; rozmówca najwyższej rangi wśród polityków S.P.D. był Min. Leber. Z osób urzędowych rozmawiali ze mna jeszcze szef Urzędu Prasy (Bundespresseamt) Dr Ahlers i przedstawiciel Min. Spraw Zagr. Dr Sahm.

Min. Leber zapytał mnie, czy nie zechciałbym być przyjęty przez Prezydenta Heinemanna. Ponieważ Pan Panie Ambasadorze ewentualność taka dopuszczał, wyraziłem swoja zgodę, zastrzegając się, że muszę prosić, aby audiencja miała charakter dyskretny $i$ aby nie ogłaszano komunikatu. Min. Leber przekazał w mojej obecności odpowiedź tę Szefowi Kancelarii i po upływie 15 minut przyszła telefoniczna odpowiedź pozytywna. Audiencja została wyznaczona na poniedziałek 20/X. o godz. 12-tej. Trwała do godz. 12.50.

Atmosfera spotkania miała charakter nie tylko uprzejmy, ale i serdeczny. Prezydent mówił o swojej sympatii i uznaniu dla narodu polskiego. Zapewniał, że celem jego jest dażenie do przekreślenia tragicznego dziedzictwa historii i stworzenie na przyszłość stosunków zaufania i przyjaźni między naszymi narodami. Stwierdzał wyraźnie, że winę historyczna ponosza dawne rzady niemieckie oraz zapewniał, że rozumie iż warunkiem wytworzenia zaufania jest wyrzeczenie się przez Niemców roszczeń terytorialnych względem Polski i uznanie naszych obecnych granic zachodnich. Stwierdził to w sposób zupełnie niedwuznacz-

\footnotetext{
${ }^{2}$ Marion Dönhoff.
} 
ny. Zaznaczał jednak, że taki zdecydowany przełom w postawie politycznej natrafia na duże opory psychologiczne. One maleja z upływem czasu, niemniej jest to czynnik poważnie hamujacy swobodna decyzje rzadu w tej kwestii. Na moje pytanie, czy można się spodziewać, że jeszcze w toku kadencji nowowybranego Bundestagu dokonany zostanie krok decydujacy $w$ sensie uznania obecnych granic, Prezydent odpowiedział oglednie: "zdawałoby sie, że tak być powinno, to bardzo możliwe" .

[Na marginesie dopisek reczny J. Czyrka: Takie pytanie osłabia nasze stanowisko w sprawie uznania oczywiście].

Prezydent wyraźnie unikał konkretnych tematów politycznych. Mocno podkreślał, że on nie rzadzi, a tylko jest strażnikiem Konstytucji i reprezentantem. Skierował rozmowe na tematy, można tak określić, natury ideowej. Wciaż podkreślał potrzebę zasadniczego, głęboko pojętego pojednania obu narodów. Podkreślał, że sprawa ta ma dla niego znaczenie moralne. Prezydent przypomniał mówiac, że był jednym z założycieli ruchu "Sühnezeichen", którego celem jest ekspiacja Niemców za zbrodnie popełnione w imieniu narodu niemieckiego. Zapytał, czy w Polsce znana jest jego mowa z 1 września br., w której ostro potępiał niemiecki nacjonalizm i historyczne zbrodnie hitleryzmu. Mówił, że dalej w tym duchu będzie oddziaływał na opinię niemiecka. Wyrażał nadzieję, że trwałe i konsekwentne przestrzeganie zasad demokracji ukształtuje nowa postawę polityczna społeczeństwa w NRF.

Pytał mnie o wrażenia z pobytu w NRF i jak oceniam obecne nastroje polityczne. Wyraził zdanie, że prasa polska informuje jednostronnie, wyolbrzymiajac strony negatywne, a nie docenia przemian pozytywnych. Podkreślałem, że mowa Władysława Gomułki z $17 /$ V.69 spowodowała też zmiany tonu w prasie polskiej. Prezydent stwierdził wtedy, że uważa mowę Gomułki za fakt o ogromnym znaczeniu. Docenia w pełni jej wagę i sadzi, że może to stanowić poczatek zasadniczego przełomu we wzajemnych stosunkach Polska - NRF. Wiaże z tym duże nadzieje, ale wyrażał obawe czy obiektywne warunki miedzynarodowej sytuacji nie ogranicza swobody działania polityki polskiej. 
W pewnej chwili, wracajac do sprawy uznania granicy na Odrze i Nysie zaznaczył, że bardzo trudno jest uzyskać aprobatę opinii dla aktów międzynarodowych majacych charakter jednostronnej koncesji i tu postawił mi pytanie, które przedtem słyszałem od wszystkich prawie politycznych rozmówców, a mianowicie czy w wypadku układu proponowanego przez Wł. Gomułkę, Polska nie mogłaby dać ze swej strony jakiegoś choćby symbolicznego świadczenia ("Gegenleistung"). W zwiazku z tym przykładem wymienił problem postawiony w memoriale ogłoszonym przez "Bensberger Kreis", a mianowicie zapewnienie Niemcom w Polsce jeszcze mieszkajacym pewnych uprawnień kulturalnych (np. szkoły, język w kościele), jak też zapewnienie im swobody wyjazdu do NRF. Odpowiedziałem, że nie ma w Polsce niemieckiej mniejszości narodowej., bo tzw. "autochtoni" tylko koniunkturalnie przyznaja się do niemieckości i dlatego postulat ten wydaje mi się pozbawiony podstaw. Prezydent sprawy tej dalej nie dyskutował. Powiedział, że chodzi o jakieś "Gegenleistung" z polskiej strony. To miałoby znaczenie i pozwoliłoby lepiej pokonać opory psychologiczne.

Dalej pytał mnie o sytuację i działalność Koła "Znak" w Polsce oraz o Wł. Gomułkę.

Ze swej strony podniosłem sprawę toczacych się rokowań gospodarczych zaznaczajac, że strona polska przywiazuje do tego wielka wage. Jest to - powiedziałem - kamień próbny dobrej woli rzadu niemieckiego. Prezydent powiedział, że docenia wage tej sprawy i że się nia interesuje. Wyraził nadzieje, że rokowania zakończa się pomyślnie.

Na zakończenie podkreślił, że niezbędna jest cnota cierpliwości, bo zasadniczy przełom w stosunkach z Polska nie da się od razu osiagnác. Prezydent ma pewność, że nowy rzad ma naprawdę najlepsza wolę, że będzie dążył do usuwania przeszkód stojacych na drodze do normalizacji stosunków z Polska i pokojowego współżycia. Zdaje się w tym punkcie zauważył, iż nie byłoby szczęśliwe, gdyby polityka polska zbyt mocno wiazała swoja sprawe ze sprawa uznania N.R.D. Jest to - powiedział - problem trudniejszy i wewnętrzno-niemiecki. Podkreśliłem w tym miejscu, że rozmawiałem też z przedstawicielami C.D.U., bo niewatpliwie obie duże partie maja wiele do powiedzenia w za- 
kresie rozwoju stosunków z Polska. Prezydent afirmował to z pełnym uznaniem.

[Na marginesie dopisek recuny J. Czyrka:

O to NRF chodzi! Chca byśmy problem uznali za wewnętrzno-niemiecki!! ].

Na zakończenie dał wyraz swoim optymistycznym nadziejom, że zmiana na lepsze, jaka się ostatnio zaznaczyła będzie poczatkiem nowej fazy i że stosunki między Polska i NRF będa się ewolucyjnie polepszać. Kurtuazyjnie dziękował mnie za odwiedziny i powiedział, że chce to uważać za dobry omen, że pierwszy raz Polak przekroczył progi tego domu. żartobliwie powiedział, że niestety on nie może pojechać do Warszawy.

Gdy chodzi o rozmowy z politykami z SPD i CDU, sprawozdanie szczegółowe złożę Panu Ambasadorowi osobiście. Tu ograniczę się do paru uwag.

Najciekawszym rozmówca był p. Kohl - deputowany C.D.U. oraz Prezes Ministrów południowej Nadrenii. Według absolutnie powszechnej opinii on ma być w gabinecie cieniów C.D.U. kandydatem na przyszłego Kanclerza. W wypadku dojścia do władzy CDU/CSU Kohl ma być kanclerzem. Dlatego Claus Bismarck, który jest szczerym i goracym przyjacielem Polski - bardzo mnie namawiał do rozmowy z Kohlem. On też rozmowe te dla mnie załatwił.

Rozmawiałem z Kohlem 2 1/2 godziny. Zrobił na mnie wrażenie b. dodatnie. Młody, tryskajacy energia, bardzo inteligentny, myślacy wnikliwie i śmiało. O sprawie polskiej mówił bardzo kategorycznie - stwierdzajac konieczność uznania naszej granicy zachodniej. Podobnie, jak Prezydent Heinemann uważał, że pojednanie z Polska jest dla Niemców sprawa moralna. Należy - mówił - doprowadzić do tego kompletnego porozumienia i przezwyciężenia wrogości, jak to nastapiło w stosunkach z Francuzami.

[Na marginesie dopisek ręczny J. Czyrka:

Moralna a nie kwestia polityczna o istotnym znaczeniu dla państwa NRF].

Natomiast dość ostro i gwałtownie oponował przeciwko wiazaniu problemu stos. z Polska ze sprawa N.R.D. O Nie- 
mieckiej Republice Demokratycznej mówił bardzo krytycznie. Stwierdzał, że uznanie granicy Odra-Nysa natrafia na opory w łonie C.D.U., ale mówił że sa one do przezwyciężenia. Wyrażał radość, że go odwiedziłem i wypowiedział poglad, że byłoby niedobrze, gdyby Polacy sprawę poprawy stosunków z Niemcami wiazali tylko z jedna Partia niemiecka t.j. z S.P.D. Wszystkie decyzje zasadnicze beda wymagały zgody dwu partii. Na pytanie, czy można liczyć na to, że decydujacy krok uznania naszych granic nastapi jeszcze w toku obecnej kadencji Bundestagu t.j. w ciagu 4 lat, odpowiedział, że sądzi, że - tak.

[Na marginesie dopisek ręczny J. Czyrka: A my się obecnie dziwimy, że NRF zwleka!].

Stwierdzić muszę, że prawie wszyscy wymienieni powyżej politycy niemieccy stwierdzali w rozmowach ze mna, że uznanie granicy odra-Nysa uważaja za nieunikniona konieczność, choć problem ten różnie ujmowali. Majonica mówił: Czas pracuje na wasza korzyść, więc nie potrzebujecie przypierać nas do muru. Widać z tego, że koncepcja jego jest gra na zwłokę. Negatywnie do postulatu uznania granicy odnosili się tylko Marx i Czaja. Z tym ostatnim rozmawiałem przypadkowo i powiedziałem co o nim sadzę. Kohl i Köppler nie biora go poważnie.

Wszyscy rozmówcy wysuwali zgodnie to zastrzeżenie, że trudno jest robić koncesje jednostronne. Jeśli N.R.F. przyjać ma propozycje Wł. Gomułki zawarcia układu na wzór traktatu w Zgorzelcu to wysuwa się sprawę wzajemności. Opinia niemiecka łatwiej układ taki strawi jeśli ze strony polskiej będzie jakaś, choćby minimalna, wzajemność. I tu przykładowo proponowano wyrzeczenie się odszkodowań wojennych lub jakieś uprawnienia kulturalne dla Niemców w Polsce zamieszkałych. To się ciagle w rozmowach powtarzało.

Ogólnie biorac odniosłem wrażenie b. dużego zdynamizowania politycznego myślenia, zwłaszcza gdy chodzi o Ostpolitik. Problem stał się żywy, ludzie o tym myśla, dyskutuja, ścieraja się poglady. Czuć duża polityczna niecierpliwość.

( Można chyba zaryzykować twierdzenie, że sprawa uznania naszych granic i normalizacji stosunków z Polska jest problemem nabrzmiałym, dojrzewajacym do rozstrzygnięcia. 
Zaraz po powrocie do Warszawy zgłoszę się do Ministerstwa dla szerszego omówienia mego pobytu w NRF.

Proszę przyjać Panie Ambasadorze, zapewnienie mego głębokiego szacunku

Paryż, 27/X.1969 r.

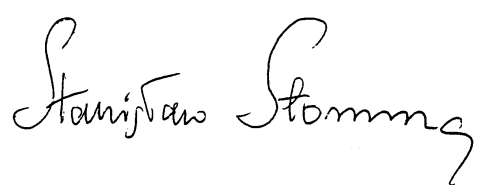

